\title{
Methicillin-resistant staphylococci
}

\author{
MARY BARBER \\ From the Department of Bacteriology, Postgraduate Medical School of London
}

SYNOPSIS Eighteen strains of Staph. pyogenes (nine penicillin-sensitive and nine penicillin-destroying) were passaged 40 to 50 times on Celbenin ${ }^{1}$ ditch plates.

All strains developed an increase in resistance to Celbenin and eight strains (four penicillinsensitive and four penicillin-destroying) were able to grow in $100 \mu \mathrm{g} / \mathrm{ml}$. or more Celbenin. Resistance was of the drug-tolerant type and none of the cultures inactivated Celbenin. There was an associated increase in tolerance to benzyl penicillin.

The highly Celbenin-resistant cultures isolated from penicillin-destroying staphylococci were in sharp contrast to those from penicillin-sensitive strains, as well as to penicillin G-tolerant staphylococci isolated in vitro, because they retained the cultural characteristics, coagulase and haemolytic activity, and mouse virulence of the parent strains, and the degree of resistance remained stable after repeated passage in the absence of Celbenin.

Three naturally occurring Celbenin-resistant strains of Staph. pyogenes isolated from infective processes were also studied. All three strains grew luxuriantly in concentrations of Celbenin up to $12 \cdot 5 \mu \mathrm{g} / \mathrm{ml}$. but very poorly in higher concentrations.

The possible significance of these findings is discussed.

The chemical isolation of the nucleus of penicillin, 6-amino penicillanic acid, followed by the preparation of a new penicillin, Celbenin (sodium 6-(2-6dimethoxybenzamido) penicillinate), which is almost completely resistant to staphylococcal penicillinase (Rolinson, Stevens, Batchelor, Wood, and Chain, 1961), is probably the most interesting and important advance in the chemotherapy of staphylococcal infection since the discovery of penicillin itself. As is well known, staphylococci resistant to benzyl penicillin can be broadly divided into two types. The penicillin-resistant strains of Staph. aureus which are, today, such a menace in our hospitals, owe their resistance to the fact that they produce an enzyme, penicillinase, which inactivates penicillin, but are usually incapable of growing in an increased concentration of unchanged antibiotic. These staphylococci, apart from penicillinase production, resemble typical, fully virulent strains. On the other hand, when staphylococci are passaged in the presence of penicillin in vitro, they fairly quickly become drug tolerant; that is to say, they are able to grow in the presence of increased concentrations of penicillin

'Methicillin is now the accepted name for the antibiotic first introduced by the Beecham Research Laboratories under the trade name Celbenin.

Received for publication 21 February 1961. but do not produce penicillinase. These staphylococci are only pale ghosts of the parent strains from which they were derived and have little or no capacity to produce coagulase or alpha-toxin or to cause disease in animals.

On the basis of these facts it has been suggested that a penicillin resistant to staphylococcal penicillinase would finally silence the adaptable staphylococcus. Before Celbenin is used too indiscriminately it seems of some importance to determine if this is indeed, the case, and to this end the present study was undertaken.

\section{EXPERIMENTAL METHODS}

Eighteen strains of Staph. pyogenes recently isolated from septic processes were selected for study. The antibiotic sensitivity patterns and phage types of the strains are given in Table I. Starting from single colonies the strains were passaged 45 to 50 times, at the rate of three to five times a week, on ditch plates containing increasing concentrations of Celbenin in the ditch. At intervals the strains were tested for sensitivity to benzyl penicillin and Celbenin by serial dilution in broth, with an inoculum consisting of $0.02 \mathrm{ml}$. of a 1/100 dilution of a six-hour shaken culture, which was equivalent to approximately $10^{5}$ to $10^{6}$ organisms.

Celbenin-resistant cultures isolated in this way were passaged in the absence of the antibiotic to see whether 
the resistance was stable. Their cultural characteristics, sensitivity to other antibiotics, phage type, and coagulase and haemolysin activity were compared with those of the parent culture from which they were derived. For haemolysin production the cultures were grown on sloppy agar and incubated for 48 hours in an atmosphere containing an excess of $\mathrm{CO}_{2}$; the cultures were then centrifuged and the supernatants tested for their capacity to haemolyse rabbit, sheep, and human red blood capsules.

Four of the Celbenin-resistant variants (two penicillinsensitive and two penicillin-resistant) were tested for mouse virulence by the technique of Selbie and Simon (1952). An injection of $0 \cdot 2 \mathrm{ml}$. of a six-hour shaken culture was injected into the right thigh; the diameter of the thigh was measured at daily intervals up to the seventh day and the degree of swelling estimated by subtracting the size of the opposite thigh.
RESULTS

DEGREE OF RESISTANCE The sensitivity to Celbenin of $\overrightarrow{\overline{\vec{c}}}$ the parent strains and the cultures after 45 to 500 passages on Celbenin plates is shown in Table I. It $\overline{\bar{\sigma}}$ will be seen that initially all 18 strains were inhibited $\frac{\bar{\omega}}{\mathcal{T}}$ by from 1.5 to $3.0 \mu \mathrm{g} . / \mathrm{ml}$. Celbenin. After passage in $\stackrel{\varnothing}{\varrho}$ Celbenin the minimum inhibitory concentration was 100 or more for nine strains, while in three cases it was only 12 . The remaining strains showed an? intermediate degree of resistance.

The rate of increase in resistance of penicillin- $\mathscr{\omega}$ sensitive and penicillinase-producing cultures is given $\overline{ }$ in Table II. It will be seen that the penicillinase- $\vec{A}$ producing cultures tended to become resistant more

TABLE I

CHARACTERISTICS OF PARENT STRAIN

Strain Antibiotic Sensitivity

\begin{tabular}{lllll}
\hline Penicillin & $\begin{array}{l}\text { Strepto- } \\
\text { mycin }\end{array}$ & $\begin{array}{l}\text { Tetra- } \\
\text { cycline }\end{array}$ & $\begin{array}{l}\text { Chloram- } \\
\text { phenicol }\end{array}$ & $\begin{array}{l}\text { Erythro- Novobiocin } \\
\text { mycin }\end{array}$
\end{tabular}

Phage Type

Sensitivity to Celbenin (M.I.C.) ( $\mu \mathrm{g} . / \mathrm{ml}$.)

Parent Strain $\begin{gathered}\text { After 45-50 } \\ \text { Passages in }\end{gathered}$
Celbenin Celbenin

\begin{tabular}{rllll}
\hline $\boldsymbol{A}$ & \multicolumn{4}{c}{ Penicillin-destroying Strains } \\
1 & R & S & S & \\
6 & R & R & R & R \\
7 & R & S & R & S \\
8 & R & R & R & S \\
14 & R & S & S & S \\
15 & R & S & S & S \\
16 & R & S & S & S \\
17 & R & S & S & S \\
18 & R & R & R & R
\end{tabular}

$\begin{array}{ll}\mathbf{S} & \text { S } \\ \mathbf{R} & \mathbf{R} \\ \mathbf{S} & \mathbf{S} \\ \mathbf{S} & \mathbf{S} \\ \mathbf{S} & \mathbf{S} \\ \mathbf{S} & \mathbf{S} \\ \mathbf{S} & \mathbf{S} \\ \mathbf{S} & \mathbf{S} \\ \mathbf{R} & \text { S }\end{array}$

$\begin{array}{ll}\text { S } & \text { S } \\ \text { R } & \text { S } \\ \text { S } & \text { S } \\ \text { S } & \text { S } \\ \text { S } & \text { S } \\ \text { S } & \text { S } \\ \text { S } & \text { S } \\ \text { S } & \text { S } \\ \text { S } & \text { R }\end{array}$

$6,7,47,53,54,75$
83
80,81
47
$6,47,53$
52,79
$52,80^{+}$
$6,47,53,77$

$\begin{array}{rr}3 \cdot 1 & >100 \\ 3 \cdot 1 & >100 \\ 3 \cdot 1 & 50 \\ 3 \cdot 1 & 25 \\ 1 \cdot 5 & >100 \\ 3 \cdot 1 & 25 \\ 3 \cdot 1 & 50 \\ 3 \cdot 1 & 50 \\ 3 \cdot 1 & >100\end{array}$

Sensitivity of to Penicillin (u. $/ m l$.

$\begin{array}{rll}B & \text { Penicillin-sensitive Strains } \\ 2 & \text { S } & \text { S } \\ 3 & \text { S } & \text { R } \\ 4 & \text { S } & \text { S } \\ 5 & \text { S } & \text { S } \\ 9 & \text { S } & \text { S } \\ 10 & \text { S } & \text { S } \\ 11 & \text { S } & \text { S } \\ 12 & \text { S } & \text { S } \\ 13 & \text { S } & \text { S }\end{array}$

$\begin{array}{ll}\text { S } & \text { S } \\ \text { R } & \text { S } \\ \text { S } & \text { S } \\ \text { S } & \text { S } \\ \text { S } & \text { S } \\ \text { S } & \text { S } \\ \text { S } & \text { S } \\ \text { R } & \text { S } \\ \text { S } & \text { S }\end{array}$

S
S
S

$\mathbf{S}$
$\mathbf{S}$
$\mathbf{S}$
$\mathbf{S}$
$\mathbf{S}$
$\mathbf{S}$
$\mathbf{S}$
$\mathbf{S}$
$\mathbf{S}$

$3 \mathrm{C}, 55,71$
$47,53,77,83$
$52 \mathrm{~A}, 79$
$6,47,53,77,83$
$3 \mathrm{C}, 55,71$
$6,42 \mathrm{E}, 53,54^{+}$
80,81
$79,53,83^{+}$
$6,47,53$

$1 \cdot 5$
$1 \cdot 5$
$1 \cdot 5$
$1 \cdot 5$
$3 \cdot 1$
$3 \cdot 1$
$1 \cdot 5$
$3 \cdot 1$
$3 \cdot 1$

12
12
12
50
$>100$
$>100$
100
$>100$
$>100$

$2 \cdot 0$
$1 \cdot 0$
$1 \cdot 0$
$100 \cdot 0$
$2 \cdot 0$
$6 \cdot 25$
$1 \cdot 0$
$100 \cdot 0$
$100 \cdot 0$

TABLE II

DEGREE OF RESISTANCE TO CELBENIN

\begin{tabular}{|c|c|c|c|c|c|c|c|c|c|c|}
\hline \multirow{3}{*}{$\begin{array}{l}\text { Concentration Celbenin } \\
\text { ( } \mu \mathrm{g} . / \mathrm{ml} \text {.) Permitting } \\
\text { Growth }\end{array}$} & \multicolumn{10}{|c|}{ Vumber of Passages } \\
\hline & \multicolumn{2}{|l|}{0} & \multicolumn{2}{|l|}{12} & \multicolumn{2}{|l|}{$20-24$} & \multicolumn{2}{|l|}{32} & \multicolumn{2}{|l|}{$45-50$} \\
\hline & $\begin{array}{l}\text { Penicillin } \\
\text { Sensitive }\end{array}$ & $\begin{array}{l}\text { Penicillin } \\
\text { Resistant }\end{array}$ & $\begin{array}{l}\text { Penicillin } \\
\text { Sensitive }\end{array}$ & $\begin{array}{l}\text { Penicillin } \\
\text { Resistant }\end{array}$ & $\begin{array}{l}\text { Penicillin } \\
\text { Sensitive }\end{array}$ & $\begin{array}{l}\text { Penicillin } \\
\text { Resistant }\end{array}$ & $\begin{array}{l}\text { Penicillin } \\
\text { Sensitive }\end{array}$ & $\begin{array}{l}\text { Penicillin } \\
\text { Resistant }\end{array}$ & $\begin{array}{l}\text { Penicillin } \\
\text { Sensitive }\end{array}$ & $\begin{array}{l}\text { Penicillin } \\
\text { Resistant }\end{array}$ \\
\hline 100 or more & $\mathbf{0}$ & 0 & $\mathbf{0}$ & 0 & 0 & 0 & 0 & 1 & 4 & 4 \\
\hline 50 & 0 & 0 & 0 & 0 & 0 & 1 & 0 & 2 & 5 & 4 \\
\hline 25 & 0 & 0 & 0 & 0 & 0 & 2 & 5 & 5 & 6 & 7 \\
\hline $12 \cdot 5$ & 0 & 0 & 0 & 0 & 2 & 6 & 5 & 8 & 6 & 9 \\
\hline $6 \cdot 25$ & 0 & 0 & 3 & 6 & 5 & 8 & 6 & 9 & 9 & \\
\hline $3 \cdot 1$ & 0 & $\mathbf{0}$ & 6 & 9 & 9 & 9 & 9 & & & \\
\hline $1 \cdot 5$ & 4 & 8 & 9 & & & & & & & \\
\hline 0.75 & 9 & 9 & & & & & & & & \\
\hline
\end{tabular}

After passage in Celbenin of 18 strains Staph. aureus, (nine sensitive to penicillin (Pen. S) and nine penicillinase producing (Pen. R)). Figures represent the number of strains resistant to various concentrations. 
quickly than the penicillin-sensitive strains. With two of the former (strain 1 and strain 6) the minimum inhibitory concentration of Celbenin was respectively 50 and $100 \mu \mathrm{g} . / \mathrm{ml}$. after 24 passages. After 45 to 50 passages, however, the same number of penicillinsensitive and penicillin-resistant cultures showed a gross increase in resistance to Celbenin.

CELBENIN DESTRUCTION Broth cultures of strains resistant to more than $100 \mu \mathrm{g}$. $/ \mathrm{ml}$. were incubated with equal quantities of a solution containing 250 $\mu \mathrm{g} . / \mathrm{ml}$. Celbenin for three hours and the active Celbenin in the mixture was subsequently estimated by the cup-plate method. In no case was there any inactivation of Celbenin.

ASSOCIATED INCREASE IN RESISTANCE TO BENZYL PENICILLIN Initially all penicillin-sensitive strains were inhibited by $0.06 \mathrm{unit} / \mathrm{ml}$. benzyl penicillin. As will be seen from Tables I and III, after passage in

\section{TABLE III}

DEGREE OF RESISTANCE TO BENZYL PENICILLIN AFTER PASSAGE IN CELBENIN OF NINE PENICILLIN-SENSITIVE STRAINS STAPH. AUREUS

\begin{tabular}{lccc}
$\begin{array}{l}\text { Concentration of Penicillin } \\
\text { (u./ml.) Permitting } \\
\text { Growth }\end{array}$ & \multicolumn{3}{c}{ No. of Passages } \\
\cline { 2 - 4 } & $20-24$ & 32 & $45-50$ \\
\hline 50 or more & - & - & 3 \\
2 & 0 & 3 & 4 \\
1 & 3 & 5 & 6 \\
0.5 & 5 & 9 & 9 \\
$0 \cdot 25$ & 8 & 9 & 9 \\
No. of strains inhibited by & 1 & 0 & 0 \\
$0 \cdot 25$ u./ml. or less & 1 & 0 &
\end{tabular}

Figures represent the number of strains resistant to various concentrations.

All strains were initially inhibited by $0.06 \mathrm{u} . / \mathrm{ml}$.

Celbenin all showed a considerable increase in resistance to benzyl penicillin. This increase was invariably greater than the increase in resistance to Celbenin but strains showing the greatest increase in resistance to one did not necessarily show the greatest increase in resistance to the other antibiotic. A strain showing a gross change in sensitivity to both antibiotics is shown in Fig. 1a.

The penicillin-destroying cultures 1 and 6 were tested for their sensitivity to penicillin using a small (approximately 500 cells) and large (approximately 1 million cells) inoculum. They retained their full capacity to produce penicillinase and in addition they had become penicillin tolerant, so that the resistance to penicillin was similar whether a small or large inoculum was tested. This was clearly demonstrated when the cultures were plated on penicillin ditch plates and examples are shown in Fig. 1b, 1c, and 1d. It will be seen that the resistant organisms in the culture obtained from strain 7 (Fig. 1d) are small colony variants whereas with strain 1 (Fig. 1b) and strain 6 (Fig. 1c) the resistant variant more closely resembles the parent strain.

CULTURAL CHARACTERISTICS AND STABILITY OF CELBENIN-RESISTANT VARIANTS All 13 strains resistant to $25 \mu \mathrm{g}$. $/ \mathrm{ml}$. or more Celbenin were compared with their parent strains in relation to cultural characteristics and were tested for the stability of their resistance to Celbenin by serial passage in nutrient agar in the absence of the antibiotic. In these respects there was a sharp difference between the cultures derived from penicillin-sensitive strains and those derived from penicillin-destroying strains.

All the six penicillin-sensitive, Celbenin-resistant variants multiplied less rapidly in artificial medium than did their parent strains and when placed on nutrient agar gave rise to colonies which varied very much in size but most of which were smaller than a typical staphylococcal colony. When plated on Celbenin ditch plates the colonies growing in the neighbourhood of the Celbenin were always small, whereas away from the ditch colonies sometimes resembled those of the parent culture. TheseCelbeninresistant variants tended to be very unstable and after only six passages in the absence of Celbenin often reverted almost completely to Celbeninsensitive organisms. Typical examples are given in Figs. 2 to 4.

On the other hand the Celbenin-resistant variants isolated from penicillin-destroying strains, with one exception (strain 7, Fig. 1d), had cultural characteristics similar to those of the parent strains from which they were derived and they retained full resistance to Celbenin after 12 passages in the absence of the antibiotic. On first isolation from ditch plates the Celbenin-resistant variants showed a slightly longer lag phase in artificial culture media and gave rise to colonies slightly smaller than those of the parent strain, but these differences became less marked after passage in the absence of Celbenin although resistance to Celbenin was maintained. A typical example is given in Fig. 5.

PHAGE TYPE OF CELBENIN-RESISTANT VARIANTS The cultures obtained from all 18 strains after 45 to 50 passages on celbenin ditch plates were all phagetyped together with their parent strains. In all cases the cultures retained their phage-sensitivity and were of the same type as the parent strain.

SENSITIVITY TO OTHER ANTIBIOTICS OF CELBENINRESISTANT VARIANTS The sensitivity of all 18 Celbenin-resistant cultures to streptomycin, tetracycline, erythromycin, and novobiocin was similar 

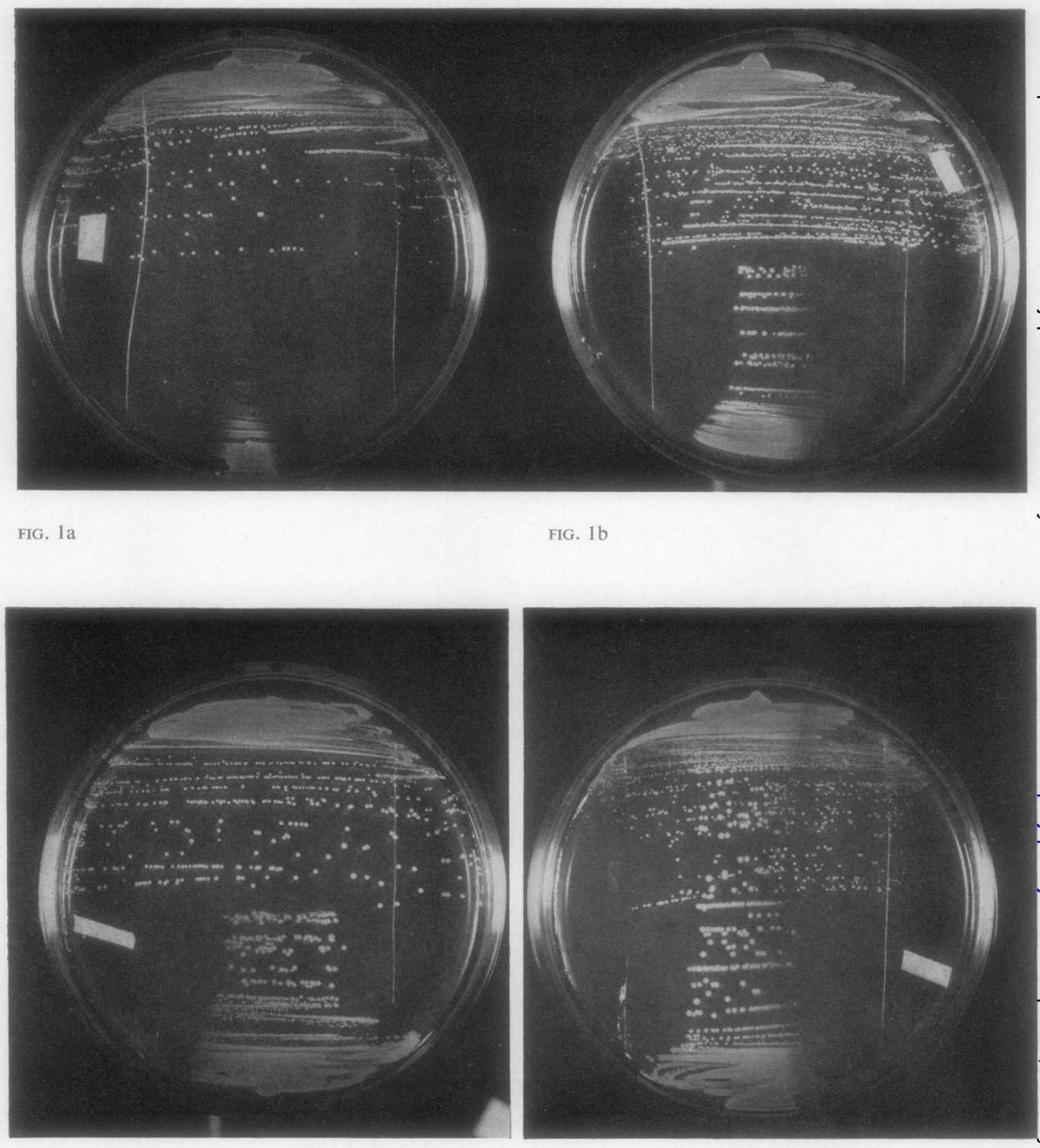

\section{(1)}

FIG. 1. Celbenin-resistant variants (upper half of plate) and parent cultures (lower half of plate) plated on double ditch plates. Ditch with white disc contains Celbenin $(50 \mu \mathrm{g} . \mathrm{ml}$.) and opposite.ditch benzyl penicillin (10 unit/ml.)

FIGs. 2-5. Typical cultures plated on ditch plates with $250 \mu \mathrm{g} . / \mathrm{ml}$. Celbenin in ditch. Lower half of each plate seeded $\stackrel{\square}{0}$ with parent culture; upper half of left plate seeded with culture immediately after 45 passages in Celbenin; upper half on right plate seeded with resistant variant after six passages on Celbenin-free medium. 


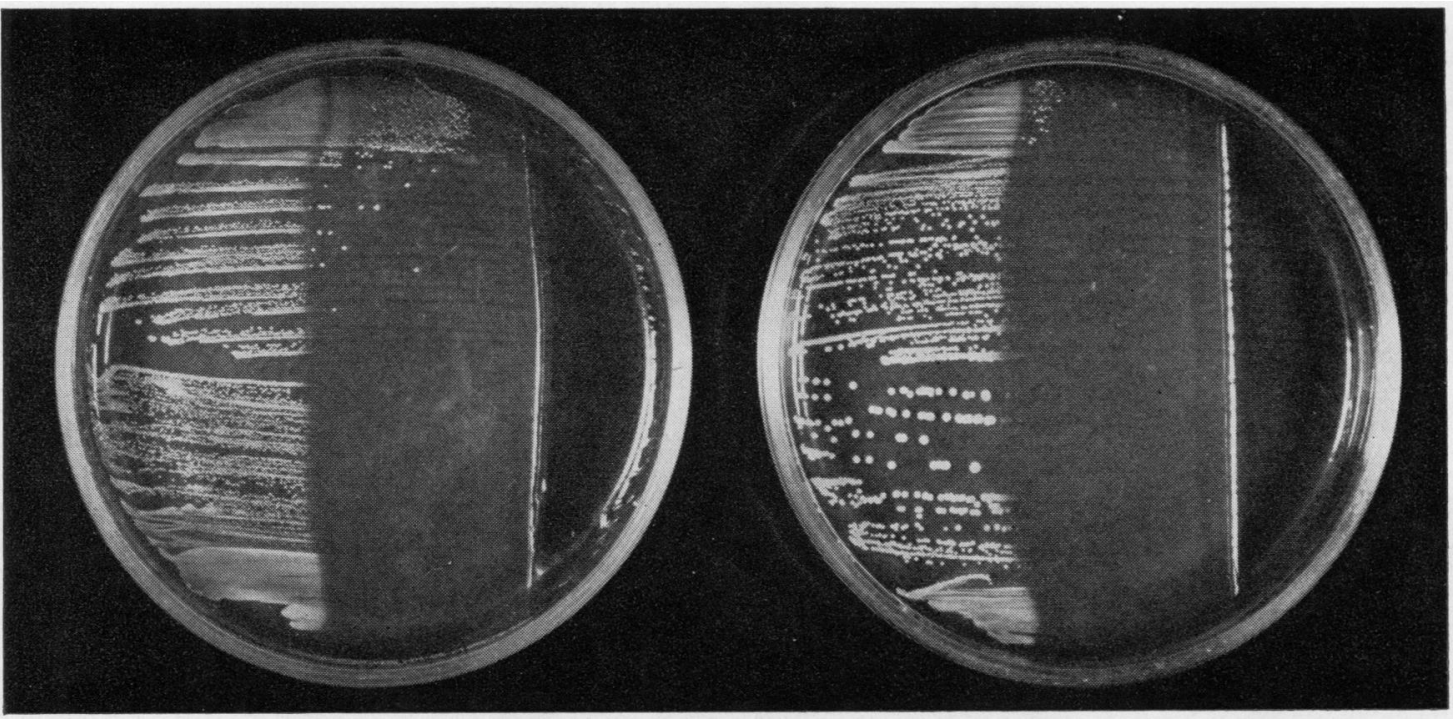

FIG. 2. Strain 10 .

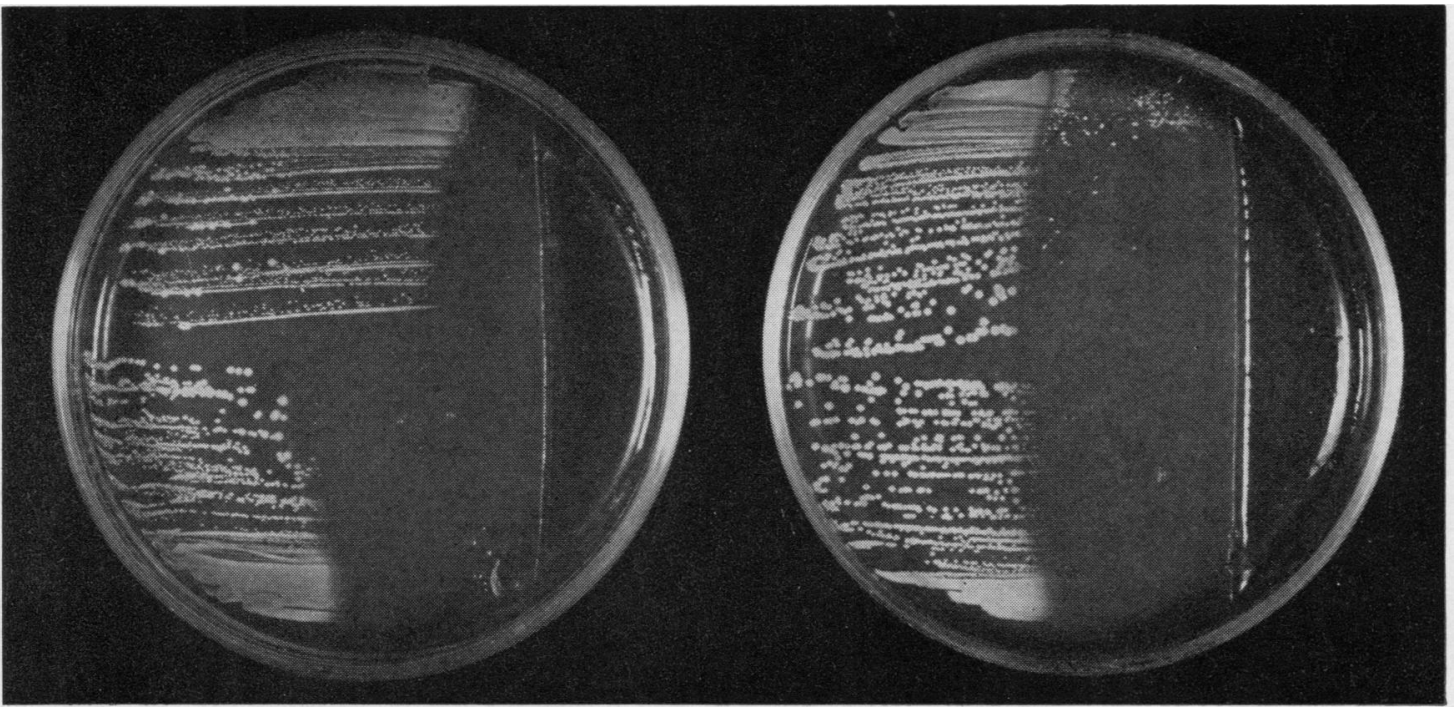

FIG. 3. Strain 12.

to that of the parent strains. Both the strains (6 and 18 ), which were initially resistant to chloramphenicol, became sensitive to this antibiotic after passage in Celbenin.

COAGULASE ACTIVITY Young broth cultures of all the Celbenin-resistant strains clotted citrated plasma in 30 to 60 minutes and there was no significant difference in the rate of clotting by parent or passaged cultures, provided the cultures were first adjusted to the same opacity.

HAEMOLYSIN PRODUCTION All the eight cultures resistant to $100 \mu \mathrm{g}$. $/ \mathrm{ml}$. or more Celbenin were tested 


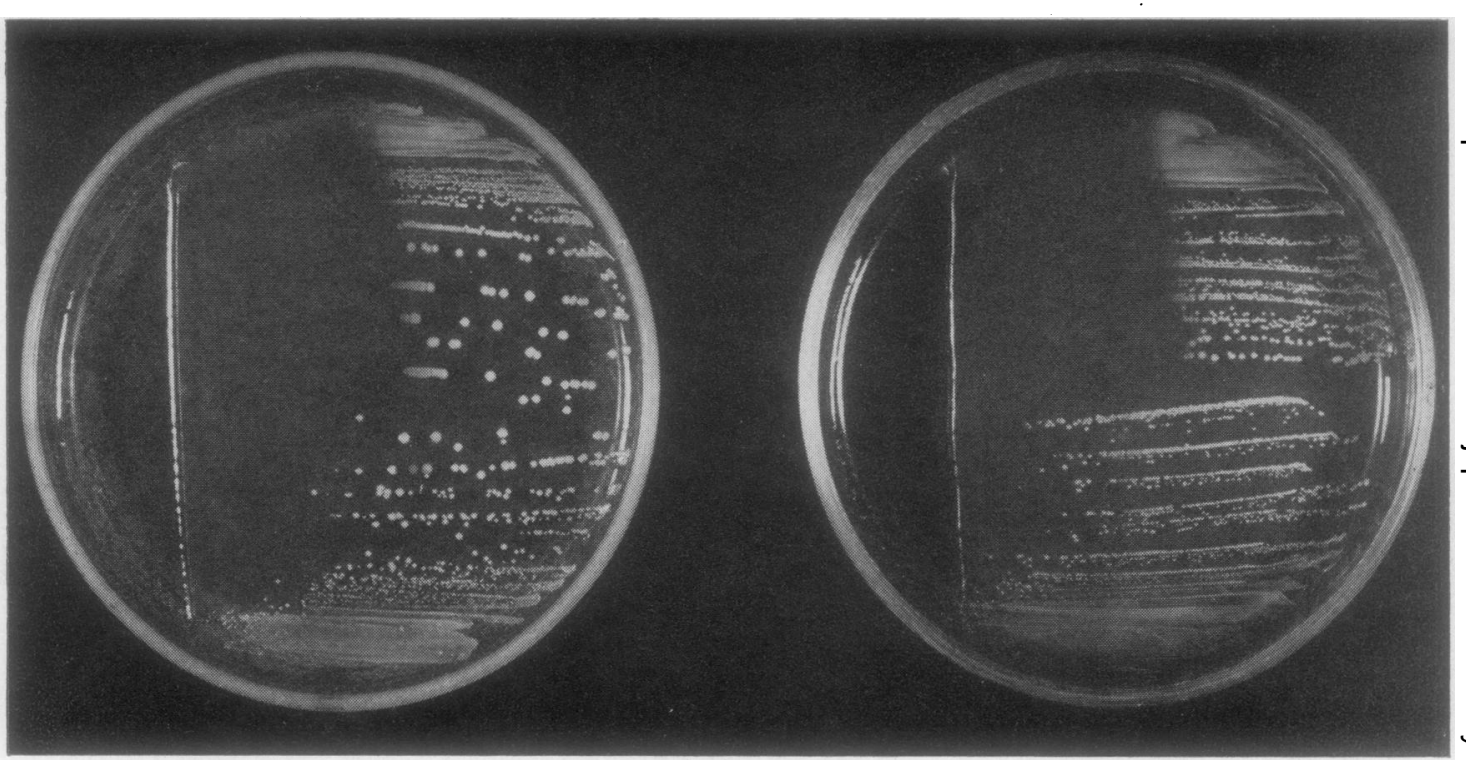

FIG. 4. Strain 13.

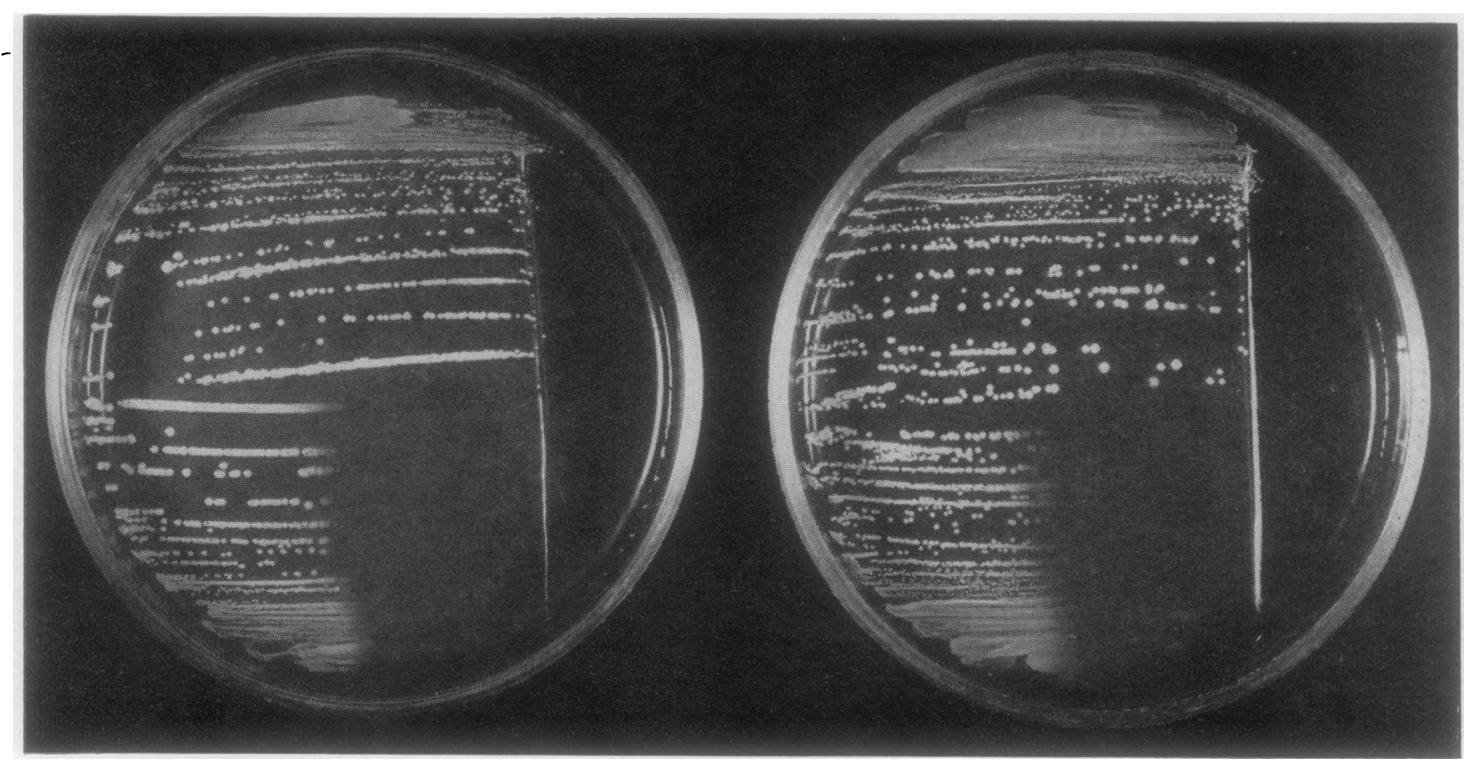

FIG. 5. Strain 6.

for haemolytic activity against rabbit, sheep, and human red blood cells. Two cultures showing an intermediate degree of resistance were tested with sheep cells only. The results are given in Table IV. In most cases the activities of the parent and the Celbenin-resistant variant were similar, but with strain 18 and strain 13 the Celbenin-resistant culture had a significantly lower activity than the parent 0 culture.

MOUSE VIRULENCE The virulence of five Celbenin- $\frac{\AA}{\mathbb{D}}$ resistant cultures was compared with that of their parent strains by measuring the amount of swelling in the thighs of mice after intramuscular injection. 
TABLE IV

HAEMOLYSIN PRODUCTION

\begin{tabular}{|c|c|c|c|c|c|c|c|c|}
\hline \multirow{2}{*}{\multicolumn{2}{|c|}{ Strain }} & \multirow{2}{*}{$\begin{array}{l}\text { Stability of } \\
\text { Resistance to } \\
\text { Celbenin }\end{array}$} & \multicolumn{3}{|c|}{ Haemolytic Titre } & \multicolumn{3}{|c|}{$\begin{array}{l}\text { Mouse Virulence Measured as } \\
\text { Average Diameter }(\mathrm{mm} .) \text { of Swelling }\end{array}$} \\
\hline & & & \multirow{2}{*}{$\begin{array}{l}\begin{array}{l}\text { Rabbit } \\
\text { Red Cells }\end{array} \\
1 / 160 \\
1 / 80\end{array}$} & \multirow{2}{*}{$\begin{array}{l}\begin{array}{l}\text { Sheep } \\
\text { Red Cells }\end{array} \\
1 / 20 \\
1 / 10\end{array}$} & \multirow{2}{*}{$\begin{array}{l}\begin{array}{l}\text { Human } \\
\text { Red Cells }\end{array} \\
1 / 8 \\
1 / 8\end{array}$} & $3 r d$ day & 5th day & 7th day \\
\hline 1 & $\begin{array}{l}\text { Parent } \\
\text { Celbenin R }\end{array}$ & $\overline{\text { Stable }}$ & & & & $\begin{array}{l}5 \cdot 7 \\
7 \cdot 5\end{array}$ & $\begin{array}{l}8 \cdot 0 \\
9 \cdot 0\end{array}$ & $\begin{array}{l}9 \cdot 0 \\
9 \cdot 0\end{array}$ \\
\hline 6 & $\begin{array}{l}\text { Parent } \\
\text { Celbenin R }\end{array}$ & $\overline{\text { Stable }}$ & $\begin{array}{l}1 / 320 \\
1 / 320\end{array}$ & $\begin{array}{l}1 / 40 \\
1 / 20\end{array}$ & $\begin{array}{l}1 / 8 \\
1 / 4\end{array}$ & $\begin{array}{l}4 \cdot 0 \\
4 \cdot 3\end{array}$ & $\begin{array}{l}4 \cdot 0 \\
4 \cdot 3\end{array}$ & $\begin{array}{l}5 \cdot 0 \\
6 \cdot 3\end{array}$ \\
\hline 7 & $\begin{array}{l}\text { Parent } \\
\text { Celbenin R }\end{array}$ & $\overline{\text { Unstable }}$ & & $\begin{array}{l}1 / 32 \\
1 / 32\end{array}$ & & $\begin{array}{l}5 \cdot 3 \\
5 \cdot 3\end{array}$ & $\begin{array}{l}4 \cdot 3 \\
4 \cdot 7\end{array}$ & $\begin{array}{l}4 \cdot 6 \\
5 \cdot 3\end{array}$ \\
\hline 14 & $\begin{array}{l}\text { Parent } \\
\text { Celbenin R }\end{array}$ & $\overline{\text { Stable }}$ & $\begin{array}{l}1 / 320 \\
1 / 320\end{array}$ & $\begin{array}{l}<1 / 5 \\
<1 / 5\end{array}$ & $\begin{array}{r}1 / 4 \\
<1 / 2\end{array}$ & & & \\
\hline 18 & $\begin{array}{l}\text { Parent } \\
\text { Celbenin R }\end{array}$ & $\overline{\text { Stable }}$ & $\begin{array}{l}1 / 320 \\
1 / 80\end{array}$ & $\begin{array}{l}1 / 10 \\
<1 / 5\end{array}$ & $\begin{array}{r}1 / 8 \\
<1 / 2\end{array}$ & & & \\
\hline 5 & $\begin{array}{l}\text { Parent } \\
\text { Celbenin R }\end{array}$ & $\overline{\text { Moderate }}$ & & $\begin{array}{l}1 / 16 \\
1 / 16\end{array}$ & & $\begin{array}{l}3 \cdot 0 \\
2 \cdot 0\end{array}$ & $\begin{array}{l}4 \cdot 0 \\
2 \cdot 7\end{array}$ & $\begin{array}{l}4 \cdot 0 \\
2 \cdot 7\end{array}$ \\
\hline 9 & $\begin{array}{l}\text { Parent } \\
\text { Celbenin R }\end{array}$ & $\overline{\text { Unstable }}$ & $\begin{array}{l}1 / 320 \\
1 / 320\end{array}$ & $\begin{array}{l}1 / 20 \\
1 / 10\end{array}$ & $\begin{array}{l}1 / 8 \\
1 / 4\end{array}$ & & & \\
\hline 10 & $\begin{array}{l}\text { Parent } \\
\text { Celbenin R }\end{array}$ & $\overline{\text { Very unstable }}$ & $\begin{array}{l}1 / 10 \\
1 / 10\end{array}$ & $\begin{array}{l}<1 / 5 \\
<1 / 5\end{array}$ & $\begin{array}{l}<1 / 2 \\
<1 / 2\end{array}$ & & & \\
\hline 12 & $\begin{array}{l}\text { Parent } \\
\text { Celbenin R }\end{array}$ & $\overline{\text { Very unstable }}$ & $\begin{array}{l}1 / 640 \\
1 / 640\end{array}$ & $\begin{array}{l}1 / 40 \\
1 / 40\end{array}$ & $\begin{array}{l}1 / 8 \\
1 / 8\end{array}$ & & & \\
\hline 13 & $\begin{array}{l}\text { Parent } \\
\text { Celbenin R }\end{array}$ & $\bar{M}_{\text {Moderate }}$ & $\begin{array}{l}1 / 320 \\
1 / 40\end{array}$ & $\begin{array}{l}1 / 10 \\
1 / 5\end{array}$ & $\begin{array}{r}1 / 4 \\
<1 / 2\end{array}$ & $\begin{array}{l}3.7 \\
1.0\end{array}$ & $\begin{array}{l}4.0 \\
1.0\end{array}$ & $\begin{array}{l}5 \cdot 3 \\
1.0\end{array}$ \\
\hline
\end{tabular}

Groups of three mice were used for each culture. The average diameter of swelling on the third, fifth, and seventh days is shown in Table IV. With the penicillin-destroying strains 1,6 , and 7 the virulence of the Celbenin-resistant strain was at least as high as that of the parent culture.

The two penicillin-sensitive strains tested, strains 5 and 13, were selected because the Celbenin-resistant variant was rather more stable in its resistance than was the case with the other strains. It will be seen that the Celbenin-resistant variant of strain 5 caused less swelling than the parent culture and that the passaged variant of strain 13 was almost avirulent.

PASSAGE IN BENZYL PENICILlin The parent cultures of the penicillin-destroying strains 1 and 6 and the penicillin-sensitive strains 5 and 12 were serially passaged on penicillin ditch plates. After 45 passages strains 1 and 6 showed respectively a two- and four-fold increase in resistance to celbenin.

Both the penicillin-sensitive strains showed a 200 -fold increase in resistance to benzyl penicillin after 45 passages, but only a four-fold increase in resistance to Celbenin.

NATURALLY OCCURRING CELBENIN-RESISTANT STRAINS For the last nine months all strains of Staph. pyogenes isolated in the laboratory of this hospital have been tested for sensitivity to Celbenin by a ditch-plate method. During this period more than 500 strains from infective processes have been tested and only one strain was found to be resistant to Celbenin. This strain came from a bedsore on a child from St. Mary's Cray who had been treated with penicillin and streptomycin, but had never had Celbenin. The phage type and sensitivity to other antibiotics of this strain (strain C.R.1) are given in Table V.

Two other naturally occurring Celbenin-resistant staphylococci have been kindly sent to me by Dr. Riddell (strain C.R.2) and Dr. Patricia Jevons (strain C.R.3). The former was isolated from a patient who lived in Farnborough and the latter was isolated from several patients in a hospital near

TABLE V

NATURALLY OCCURRING CELBENIN-RESISTANT STRAINS

Strain Source

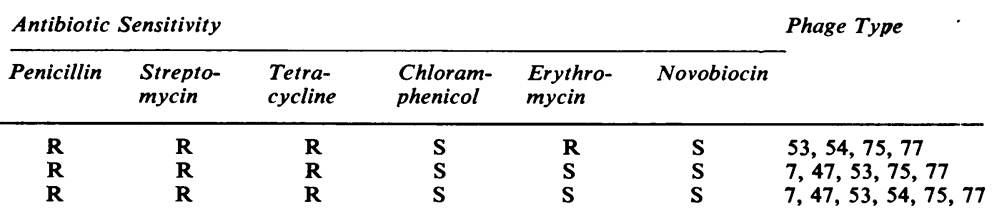

C.J2.1 General hospital

C.R.2 General hospital

C.K.3 Central Public Health Laboratory 
Guildford (see Jevons, 1961). None of these patients had been treated with Celbenin. The sensitivity to other antibiotics and phage type of these strains are given in Table V. It will be seen that all three strains belonged to phage group 3 and were of closely related, if not the same, phage types.

Degree of Resistance to Celbenin All three strains behaved in a similar way in the presence of Celbenin. When sensitivity tests were carried out in fluid media with a small or moderate-sized inoculum and read after 24 hours' incubation the strains showed only a moderate degree of resistance and were inhibited by from 12.5 to $25 \mu \mathrm{g}$. $/ \mathrm{ml}$. Celbenin. On solid medium only a small number of colonies grew in the presence of a high concentration of Celbenin, and moreover these colonies were not visible after overnight incubation and even after 48 hours' incubation were much smaller than typical staphylococcal colonies.

Passage in Celbenin After five passages on Celbenin ditch plates all the strains grew in 250 to $500 \mu \mathrm{g} . / \mathrm{ml}$. of Celbenin after overnight incubation. On solid media containing $5 \mu \mathrm{g} . / \mathrm{ml}$. colonies were very variable in size, ranging from typical staphylococcal colonies to very tiny ones. On plates containing $25 \mu \mathrm{g} . / \mathrm{ml}$. or more all colonies were small.

Stability of Resistance After six passages on nutrient agar in the absence of Celbenin all three strains had a reaction to Celbenin similar to that of the original strains.

It is thus apparent that these three naturally resistant organisms on first isolation consisted predominantly of cells with only a moderate degree of resistance to Celbenin. After a few passages in the presence of the antibiotic the highly resistant organisms were selected at the expense of the more sensitive cells. But although the highly resistant cells were capable of growth in the presence of very large concentrations of Celbenin, their degree of growth and colony size was much less when the Celbenin concentration was $25 \mu \mathrm{g}$. $/ \mathrm{ml}$. or more than with lower concentrations.

\section{DISCUSSION}

After repeated passage on Celbenin ditch plates all of 18 strains of Staph. pyogenes showed an increase in resistance to Celbenin and eight of the strains were capable of growing in 100 or more $\mu \mathrm{g} . / \mathrm{ml}$. Celbenin. Resistance was of the drug-tolerant type, and none of the resistant strains inactivated Celbenin. There was an associated increase in tolerance to benzyl penicillin.

As is well known, staphylococci readily develop resistance of this type in vitro to benzyl penicillin. There is, however, a very remarkable difference between in vitro induced benzyl-penicillin-resistant $\frac{\text { जै }}{5}$ staphylococci and the Celbenin-resistant organisms isolated from penicillinase-producing staphylococci reported in this communication.

Thus staphylococci trained to be penicillin $\frac{\bar{C}}{0}$ G-tolerant, although of several different types (see $\overline{\bar{c}}$ Barber, 1953), always grow much less luxuriantly $\overparen{\nabla}$ than typical staphylococci and are of reduced coagulase and alpha-toxin activity and virulences (Rake, McKee, Hamre, and Houck, 1944; Spink,. Ferris, and Vivino, 1944; Blair, Carr, and Buchman, $\overrightarrow{\vec{\omega}}$ 1946). It is probably on account of these facts that $\stackrel{\omega}{\omega}$ they are rarely encountered in clinical practice. These $\frac{7}{0}$ organisms are also extremely unstable and tend to lose their resistance to penicillin rapidly on subculture in the absence of antibiotic.

Four of the penicillin-destroying strains used in the present investigation have yielded stable Celbenin-응 tolerant cultures which are resistant to 100 or more $\mu \mathrm{g} . / \mathrm{ml}$. Celbenin. All four resembled the parent $\subset$ strains in cultural characteristics and coagulase production, and in three cases the haemolytic activity $\vec{\varphi}$ was similar. Two of the strains were tested for mouse 9 virulence by injection into the thigh and the Celbeninresistant cultures were shown to be as virulent as the parent strains.

Four of the penicillin-sensitive strains yielded cultures with a similar degree of tolerance to $\frac{\varnothing}{\varnothing}$ Celbenin, but in other respects were in sharp contrast $\varrho$ to the cultures isolated from penicillin-destroying $\overrightarrow{\vec{O}}$ strains. Thus the cultures were unstable and tended $\exists$ to become Celbenin-sensitive in the absence of the antibiotic. The resistant cultures grew much less: luxuriantly than their parent strains. On subculture용 in the absence of Celbenin these cultures rapidly reverted to cultures resembling the parent strain in sensitivity to Celbenin and colonial appearances.

No explanation has been found for the difference $₹$ in the Celbenin-resistant organisms isolated fromo penicillin-destroying and penicillin-sensitive staphylococci. In neither case do the resistant organismso inactivate Celbenin. But, as pointed out by Hayes (1957), two mutations are probably involved in the production of penicillinase-producing staphylococci. $N$ Only mutation 2 is concerned with the production of ${ }_{\mathrm{W}}$ inducible penicillinase, but this mutation cannot 0 express itself in the absence of mutation 1 which results in cells able constitutively to produce very $\frac{0}{\Phi}$ small amounts of the enzyme. Celbenin is not com- $\stackrel{0}{+}$ pletely resistant to staphylococcal penicillinase and it is possible that mutation 1 would render staphylo-

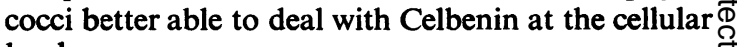
level.

Naturally occurring Celbenin-resistant strains of $\frac{\varrho}{\sigma}$ Staph. pyogenes are not common. Jevons (1961), of the Central Public Health Laboratory, only en- 
countered one (the strain referred to in this paper as C.R.3) in a study of 4,340 strains from routine material from hospitals. This and the two other strains described here grow very poorly in the presence of more than 12 to $25 \mu \mathrm{g}$. $/ \mathrm{ml}$. Celbenin and may, therefore, lose much of their virulence in the presence of the antibiotic.

Since naturally occurring Celbenin-resistant organisms are not only rare but of doubtful clinical significance, it has been suggested (Rolinson, 1961 ; Knox, 1961) that Celbenin-resistant staphylococci are not likely to be of clinical importance. This may be the case. Certainly staphylococci cannot develop resistance to Celbenin at the rate they can do to erythromycin and novobiocin, and it is unlikely that a gross increase in resistance to Celbenin will occur during the treatment of a single patient.

But two at least of the Celbenin-tolerant cultures isolated in this investigation from penicillinase-producing staphylococci have apparently retained their virulence. Such organisms might arise by passage in patients treated with Celbenin, if the antibiotic be used extensively in wards where cross-infection is occurring. These two Celbenin-tolerant cultures retained their full capacity to produce penicillinase, unlike the strains described by Fairbrother and Taylor (1961).

Clearly Celbenin-resistant staphylococci are a potential danger. It should be remembered that staphylococci do not readily become resistant to the tetracyclines and early reports on chlortetracycline suggested that tetracycline-resistant staphylococci were unlikely to be of clinical importance (Paine, Collins, and Finland, 1948; Finland, Collins, and Paine, 1948). It is unwise to assume that the staphylococcus has met its match. In the meantime Celbenin should be used with discrimination, in which case it will remain an invaluable weapon for the treatment of staphylococcal infection.

It is a pleasure to thank Dr. M. P. Jevons, of the Central Public Health Laboratory, and Dr. R. W. Riddell, of the Brompton Hospital, for sending me naturally occurring Celbenin-resistant strains and supplying me with full details of these strains including the phage-types. I am also very grateful to the directors of Beecham Research Laboratories for a free supply of Celbenin.

\section{REFERENCES}

Barber, M. (1953). J. gen. Microbiol., 8, 111.

Blair, J. E., Carr, M., and Buchman, J. (1946). J. Immunol., 52, 281

Fairbrother, R. W., and Taylor, G. (1961). Lancet, 1, 473.

Finland, M., Collins, H. S., and Paine, T. F. Jr. (1948). J. Amer. med. Ass., 138, 946.

Hayes, W. (1957). In Ciba Foundation Symposium on Drug Resistance in Micro-organisms, p. 275. Churchill, London.

Jevons, M. P. (1961). Brit. med. J., 1, 124.

Knox, R. (1961). Ibid., 1, 126.

Paine, T. F. Jr., Collins, H. S., and Finland, M. (1948). J. Bact., 56, 489.

Rake, G., McKee, C. M., Hamre, D. M., and Houck, C. L. (1944). J. Immunol., 48, 271.

Rolinson, G. N. (1961). Brit. med. J., 1, 125.

-, Stevens, S., Batchelor, F. R., Wood, J. C., and Chain, E. B. (1961). Lancet, 1, 562.

Selbie, F. R., and Simon, R. D. (1952). Brit. J. exp. Path., 33, 315.

Spink, W. W., Ferris, V., and Vivino, J. J. (1944). Proc. Soc. exp. Biol. (N.Y.), 55, 210. 